\title{
REVIEWS
}

\section{Rate of Preventable Mortality in Hospitalized Patients: a Systematic Review and Meta-analysis}

\author{
Benjamin A. Rodwin, $M D^{1,2}\left(0\right.$, Victor P. Bilan, $M D^{1,2}$, Naseema B. Merchant, $M D^{1,2}$, \\ Catherine G. Steffens ${ }^{2}$, Alyssa A. Grimshaw, MSLIS ${ }^{3}$, Lori A. Bastian, MD, MPH ${ }^{1,2}$, and \\ Craig G. Gunderson, $M D^{1,2}$
}

'Department of Medicine, Yale University School of Medicine, New Haven, CT, USA; ${ }^{2}$ VA Connecticut Healthcare System, West Haven, CT, USA;
${ }^{3}$ Harvey Cushing/John Hay Whitney Medical Library, Yale University School of Medicine, New Haven, CT, USA.

BACKGROUND: The number of preventable inpatient deaths in the USA is commonly estimated as between 44,000 and 98,000 deaths annually. Because many inpatient deaths are believed to be preventable, mortality rates are used for quality measures and reimbursement. We aimed to estimate the proportion of inpatient deaths that are preventable.

METHODS: A systematic literature search of Medline, Embase, Web of Science, and the Cochrane Library through April 8, 2019, was conducted. We included case series of adult patients who died in the hospital and were reviewed by physicians to determine if the death was preventable. Two reviewers independently performed data extraction and study quality assessment. The proportion of preventable deaths from individual studies was pooled using a random-effects model.

RESULTS: Sixteen studies met inclusion criteria. Eight studies of consecutive or randomly selected cohorts including 12,503 deaths were pooled. The pooled rate of preventable mortality was 3.1\% (95\% CI 2.2-4.1\%). Two studies also reported rates of preventable mortality limited to patients expected to live longer than 3 months, ranging from 0.5 to $1.0 \%$. In the USA, these estimates correspond to approximately 22,165 preventable deaths annually and 7150 deaths for patients with greater than 3month life expectancy.

DISCUSSION: The number of deaths due to medical error is lower than previously reported and the majority occur in patients with less than 3-month life expectancy. The vast majority of hospital deaths are due to underlying disease. Our results have implications for the use of hospital mortality rates for quality reporting and reimbursement.

STUDY REGISTRATION: PROSPERO registration number CRD42018095140.

KEY WORDS: patient safety; preventable death; medical error.

Electronic supplementary material The online version of this article (https://doi.org/10.1007/s11606-019-05592-5) contains supplementary material. which is available to authorized users.

Prior presentations Society of Hospital Medicine National Conference, March 2019. Society of General Internal Medicine National Conference, May 2019

Received August 29, 2019

Revised October 8, 2019

Accepted November 28, 2019

Published online January 21, 2020
J Gen Intern Med 35(7):2099-106

DOI: $10.1007 / \mathrm{s} 11606-019-05592-5$

(c) Society of General Internal Medicine (This is a U.S. government work and not under copyright protection in the U.S.; foreign copyright protection may apply) 2020

\section{INTRODUCTION}

In 1999, the Institute of Medicine (IOM) published its seminal report on medical errors, To Err Is Human: Building a Safer Health System. ${ }^{1}$ This widely cited analysis extrapolated from two studies of adverse events in hospitals and concluded that between 44,000 and 98,000 Americans die annually due to preventable medical error. The two referenced studies evaluated deaths from medical error by first determining the frequency of adverse events in hospitals and then separately deciding whether the adverse event was preventable and whether the adverse event caused harm. ${ }^{2,3}$ More recently, a report including several additional studies concluded that medical error causes more than 250,000 inpatient deaths per year in the USA, making it the third leading cause of death behind only cancer and heart disease. ${ }^{4}$

Studies that review series of admissions and determine whether adverse events occurred, whether the events were preventable, and what harms resulted have been criticized for indirectness when used to estimate the number of deaths due to medical error. ${ }^{5,6}$ In contrast, studies of inpatient deaths offer a more direct way of estimating the rate of preventable deaths. We undertook a systematic review and meta-analysis of studies that reviewed case series of inpatient deaths and used physician review to determine the proportion of preventable deaths.

\section{METHODS}

\section{Data Sources and Searches}

The Meta-analysis of Observational Studies in Epidemiology (MOOSE) and the Preferred Reporting Items for Systematic Reviews and Meta-Analyses (PRISMA) statements for reporting systematic reviews were used for our study. ${ }^{7,8} \mathrm{We}$ searched for observational studies that reviewed case series of inpatient deaths and used physician review to determine the 
frequency of death due to preventable error. A librarian conducted literature searches for relevant articles in Ovid Medline All, Ovid Embase, Web of Science, and the Cochrane Library from database inception through April 8, 2019. Details of the full search strategy are listed in Appendix Table 4. Additional searches were performed for governmental reports using the gray literature search tool produced by the Canadian Agency for Drugs and Technologies in Health (CADTH). ${ }^{9}$ We also searched for publications by the Institute of Healthcare Improvement (IHI), The Joint Commission, and The World Health Organization. Lastly, we used Web of Science and Scopus to search conference proceedings from American College of Physicians, IHI National Forum, and International Forum on Quality and Safety in Healthcare. The review protocol was registered in the Prospero database under registration number CRD42018095140.

\section{Study Selection}

All studies of case series of adult patients who died in the hospital and were reviewed by physicians to determine if the death was preventable were included. Non-English studies were included and translated using Google Translate, which has been shown to be a viable tool for the purpose of abstracting data for systematic reviews. ${ }^{10}$ Studies which evaluated a series of inpatient admissions to determine if there was a preventable adverse event, and then determined if that adverse event contributed to death, such as those included in the 1999 Institute of Medicine report, were excluded. We primarily searched for studies of consecutive or randomly selected inpatient deaths, but also included studies that used cohorts with selection criteria but analyzed these separately. Studies limited to specific populations such as pediatric, trauma, or maternity patients were excluded because our primary research question was to determine the overall rate of preventable mortality in hospitalized patients and these populations are less generalizable. Two authors (BR and CG) screened all titles and abstracts for full text review, and independently reviewed them for inclusion. Citations of the included studies were also screened. Disagreement was resolved by consensus.

\section{Data Extraction and Quality Assessment}

A standardized data extraction form was used to document study characteristics including year of publication; country of study; setting; number of deaths reviewed; cohort description; definition of preventable mortality; method of determination of preventability, whether errors prior to hospitalization were included; and inter-rater reliability for preventability. Data were extracted independently by two authors (BR and CG). Two authors (BR and LB) independently assessed study quality using a modified Newcastle-Ottawa Quality Assessment Scale (NOS) for Cohort Studies (Appendix Table 5) ${ }^{11}$ Differences were resolved by consensus. Three of the original NOS components were not relevant given the designs of the included studies. Instead, we added components for whether two or more reviewers independently assessed the preventability of the deaths and reported a measure of inter-rater reliability, and whether clear criteria for preventability were defined along with a method of arbitration for differences of opinion between reviewers. In determining the rate of preventable deaths, we included deaths which were determined by a majority of reviewers to have a $>50 \%$ likelihood of preventability. Lastly, when possible, we limited the assessment of preventability to events that occurred during the hospitalization rather than to events that occurred prior to the hospitalization.

\section{Data Synthesis and Analysis}

The preventable mortality rates and $95 \%$ confidence intervals (CIs) for the included studies were calculated using the score method. ${ }^{12}$ Mortality rates were pooled using a random-effects model as described by DerSimonian and Laird ${ }^{13}$ with Freeman-Tukey double arcsine transformation. ${ }^{14}$ Betweenstudy heterogeneity was estimated using the $I^{2}$ statistic. Statistical analysis was performed using metaprop command in Stata/MP, version 15.1 (StataCorp, College Station, Texas).

\section{RESULTS}

The initial electronic search found 3835 manuscripts, of which 731 were duplicates (Fig. 1). Of the 3104 manuscripts reviewed, 3011 were excluded based on title and abstract review, leaving 93 for full text review. Of these, 16 met criteria for study inclusion. The main reasons that studies were excluded after full text review were that they were not the correct study design or did not report original data. Of the 16 included studies, eight were of random or consecutive groups of patients and eight were of cohorts with selection criteria. The characteristics of the eight random or consecutive cohorts are shown in Table 1 . The 2015 study by Hogan included patients that were previously reported by their group in 2012 - only the new patients in the 2015 study are presented in Table 1 to avoid duplication. Of the eight studies, three were from the UK, ${ }^{16,17,19}$ two from Norway, ${ }^{20,22}$ and one each from Denmark, ${ }^{15}$ the Netherlands, ${ }^{18}$ and Canada. ${ }^{21}$ Four of the studies included patients from multiple hospitals. ${ }^{16,}{ }^{18-20}$ All studies defined preventable deaths as those that were rated as greater than $50 \%$ chance of having been preventable. Seven of the studies used a Likert scale to define preventability ${ }^{15-20,22}$ while one used a scale of $0-100 \% .{ }^{21}$ Five studies used multiple reviewers, three of which used consensus to arbitrate differences of opinion, ${ }^{15,17,20}$ one used a third reviewer, ${ }^{18}$ and one used latent class analysis. ${ }^{21}$ Six of the studies included adverse events prior to admission. ${ }^{16-19,21,22}$ Only the study by Hogan in 2012 separately reported the number of preventable deaths that occurred during the admission alone versus the number that occurred prior to admission. This study found that 13 of 52 (25\%) preventable deaths were related to prior outpatient events.] $>$

Table 2 describes the eight included studies of cohorts with selection criteria. Three of these studies were from the USA, ${ }^{23}$, 24,28 two from France, ${ }^{25,} 26$ and one each from the UK, ${ }^{27}$ the Netherlands, ${ }^{30}$ and Taiwan. ${ }^{29}$ These cohorts had varied 
selection criteria. Four included only patients with certain diagnoses, generally selected to increase the number of possible preventable deaths. ${ }^{23,24,27,28}$ Two studies included only emergency department admissions, one which was limited to patients not admitted to an intensive care unit (ICU) who died within $72 \mathrm{~h}^{26}$ and another which included only patients who died within $24 \mathrm{~h}$ of admission. ${ }^{29}$ One study was limited to ICU deaths only. ${ }^{25}$ Lastly, one study only included deceased patients that were positive for certain "trigger tool" events such as unplanned readmissions, unplanned transfer to intensive care, or healthcare-related adverse events. ${ }^{30}$ Five studies defined preventable deaths as those that were rated as greater than $50 \%$ chance of having been preventable. ${ }^{23-27}$ The three remaining studies used different definitions; one included deaths that were "somewhat likely" to have been preventable, ${ }^{28}$ one included deaths that were "potentially" preventable, ${ }^{30}$ and one used a yes/no determination of preventability. ${ }^{29}$
Table 3 describes the study quality assessment based on a modified NOS. Study quality was assessed based on seven elements, each of which could earn one point if certain standards were met. The eight studies with random or consecutive cohorts all received between 6 and 7 points, depending on whether they had two reviewers independently review deaths for preventability and reported inter-rater reliability. The studies with cohorts with selection criteria had more varied NOS scores, ranging between 4 and 6 . All lost points for lack of representativeness, and several lost points for using only one reviewer or not reporting inter-rater reliability. ${ }^{25,}{ }^{27,}{ }^{30}$ Lastly, two studies lost points for lack of clarity around the determination of preventability. ${ }^{29,} 30$

Figure 2 demonstrates the pooled and individual study preventable mortality rates for hospitalized patients using random-effects meta-analysis for the eight studies which used consecutive or randomly selected cohorts. The overall pooled

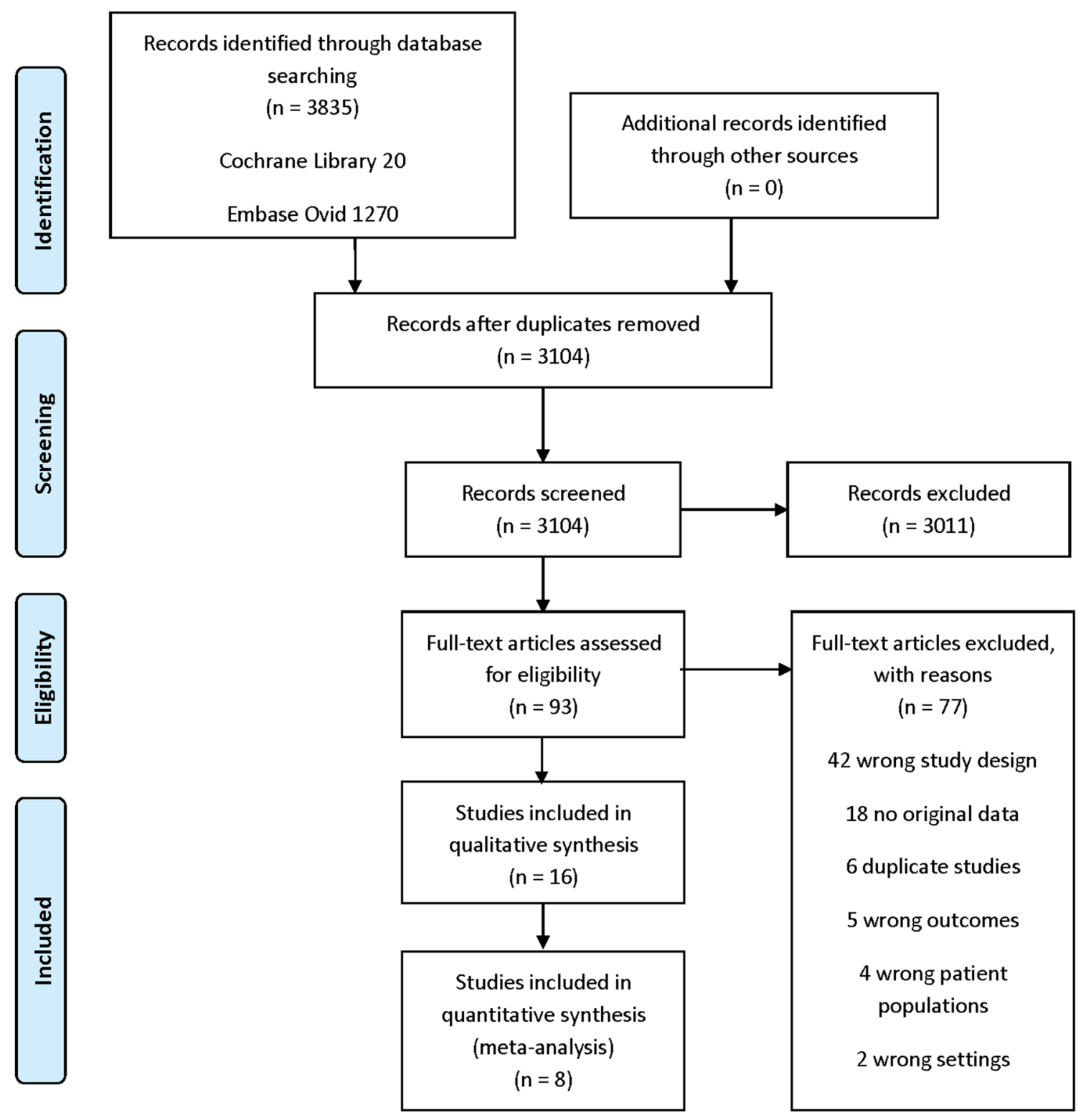

Figure 1 Flow diagram of study selection. 
Table 1 Characteristics of Included Studies from Random or Consecutive Cohorts

\begin{tabular}{|c|c|c|c|c|c|c|c|}
\hline Author & Setting & $\begin{array}{l}\text { Number of } \\
\text { deaths } \\
\text { reviewed }\end{array}$ & Cohort & $\begin{array}{l}\text { Definition of } \\
\text { preventable }\end{array}$ & $\begin{array}{l}\text { Determination of } \\
\text { preventable }\end{array}$ & $\begin{array}{l}\text { Included } \\
\text { events } \\
\text { before } \\
\text { admission }\end{array}$ & $\begin{array}{l}\text { Inter-rater } \\
\text { reliability for } \\
\text { preventability }\end{array}$ \\
\hline $\begin{array}{l}\text { Engel, } \\
2007\end{array}$ & $\begin{array}{l}\text { Single } \\
\text { hospital, } \\
\text { Denmark }\end{array}$ & 48 & $\begin{array}{l}\text { Consecutive } \\
\text { deaths, no } \\
\text { exclusions }\end{array}$ & $\begin{array}{l}0-100 \% \text { scale, } \\
>50 \%= \\
\text { preventable }\end{array}$ & $\begin{array}{l}4 \text { reviewers, } \\
\text { consensus arbitration }\end{array}$ & NR & NR \\
\hline $\begin{array}{l}\text { Hogan, } \\
2012\end{array}$ & $\begin{array}{l}10 \text { hospitals, } \\
\text { UK }\end{array}$ & 1000 & $\begin{array}{l}\text { Consecutive. } \\
\text { Excluded } \\
\text { obstetric, } \\
\text { psychiatric, } \\
\text { pediatric }\end{array}$ & $\begin{array}{l}\text { 6-point scale, } \\
\geq 4= \\
\text { preventable }\end{array}$ & $\begin{array}{l}\text { Many with one } \\
\text { reviewer, preventable } \\
\text { deaths reviewed by } \\
\text { expert }\end{array}$ & Yes & Kappa 0.49 \\
\hline $\begin{array}{l}\text { Sorinola, } \\
2012\end{array}$ & $\begin{array}{l}\text { Single } \\
\text { hospital, UK }\end{array}$ & 400 & $\begin{array}{l}\text { Consecutive. } \\
\text { Excluded } \\
\text { obstetric, } \\
\text { psychiatric, } \\
\text { pediatric }\end{array}$ & $\begin{array}{l}\text { 6-point scale, } \\
\geq 4= \\
\text { preventable }\end{array}$ & $\begin{array}{l}\text { Multiple reviewers, } \\
\text { consensus arbitration }\end{array}$ & Yes & NR \\
\hline $\begin{array}{l}\text { Baines, } \\
2015\end{array}$ & $\begin{array}{l}41 \text { hospitals, } \\
\text { Netherlands }\end{array}$ & 5990 & $\begin{array}{l}\text { Excluded } \\
\text { obstetric, } \\
\text { psychiatric, } \\
\text { pediatric }\end{array}$ & $\begin{array}{l}\text { 6-point scale, } \\
\geq 4= \\
\text { preventable }\end{array}$ & $\begin{array}{l}\text { 1-2 reviewers, used } \\
\text { 3rd reviewer to } \\
\text { arbitrate }\end{array}$ & Yes & Kappa $0.40^{*}$ \\
\hline $\begin{array}{l}\text { Hogan, } \\
2015\end{array}$ & $\begin{array}{l}24 \text { hospitals, } \\
\text { UK }\end{array}$ & 2400 & $\begin{array}{l}\text { Excluded } \\
\text { obstetric, } \\
\text { psychiatric, } \\
\text { pediatric }\end{array}$ & $\begin{array}{l}\text { 6-point scale, } \\
\geq 4= \\
\text { preventable }\end{array}$ & $\begin{array}{l}\text { Many with one } \\
\text { reviewer, preventable } \\
\text { deaths reviewed by } \\
\text { expert }\end{array}$ & Yes & Kappa 0.45 \\
\hline $\begin{array}{l}\text { Flaatten, } \\
2017\end{array}$ & $\begin{array}{l}3 \text { hospitals, } \\
\text { Norway }\end{array}$ & 1185 & $\begin{array}{l}\text { Consecutive } \\
\text { deaths, no } \\
\text { exclusions }\end{array}$ & $\begin{array}{l}\text { 5-point scale, } \\
\geq 4= \\
\text { preventable }\end{array}$ & $\begin{array}{l}\text { Multiple reviewers, } \\
\text { consensus arbitration }\end{array}$ & No & NR \\
\hline $\begin{array}{l}\text { Kobewka, }^{21} \\
2017\end{array}$ & $\begin{array}{l}\text { Single } \\
\text { hospital, } \\
\text { Canada }\end{array}$ & 480 & $\begin{array}{l}\text { Consecutive } \\
\text { deaths, no } \\
\text { exclusions }\end{array}$ & $\begin{array}{l}0-100 \% \text { scale, } \\
>50 \%= \\
\text { preventable }\end{array}$ & $\begin{array}{l}\text { Four reviewers, latent } \\
\text { class analysis to } \\
\text { arbitrate }\end{array}$ & Yes & ICC 0.68 \\
\hline $\begin{array}{l}\text { Rogne, } \\
2019\end{array}$ & $\begin{array}{l}2 \text { hospitals, } \\
\text { Norway }\end{array}$ & 1000 & $\begin{array}{l}\text { Excluded } \\
\text { obstetric, } \\
\text { psychiatric, } \\
\text { pediatric }\end{array}$ & $\begin{array}{l}\text { 6-point scale, } \\
\geq 4= \\
\text { preventable }\end{array}$ & $\begin{array}{l}\text { Single reviewer } \\
\text { unless there were } \\
\text { questions, then group }\end{array}$ & Yes & NR \\
\hline
\end{tabular}

$I C C$, intraclass correlation coefficient; NR, not reported

* Kappa reported for only part of the cohort that used two reviewers

rate was $3.1 \%$ (95\% CI 2.2-4.1\%). Individual studies ranged from 1.4 to $4.4 \%$ preventable mortality with statistically significant evidence for heterogeneity $\left(I^{2}=84 \%, p<0.001\right)$. The eight studies with selection criteria reported rates of preventable mortality ranging from 0.5 to $26.9 \%$. One study from 1988 reported that $26.9 \%$ of 182 deaths for myocardial infarction, stroke, or pneumonia were $>50 \%$ likely to have been preventable. ${ }^{23}$ A study which evaluated 124 patients from the Emergency Department who died within $24 \mathrm{~h}$ of admission found that $25.8 \%$ of these deaths could have been prevented. ${ }^{29}$ Another study from 1994 reported that $21.6 \%$ of 22 deaths from certain diagnostic groups were at least "somewhat likely" to have been preventable. ${ }^{28}$ A large recent study from the Netherlands reported $9.4 \%$ of 2182 deaths as "potentially preventable." The remaining studies with selection criteria reported rates of $0.5-6.2 \%$ preventable deaths.] $\rightarrow$

One study of consecutive patients ${ }^{21}$ and one with selection criteria $^{24}$ reported rates of preventable mortality limited to patients expected to live longer than 3 months. The rate of preventable mortality for these patients ranged from 0.5 to $1.0 \%$.

Appendix Table 6 lists the types of error which led to preventable death from the included studies. Six of the studies listed the frequency of different types of error which led to preventable death, ${ }^{16-18,22,23,29}$ and four provided a narrative summary of the possibly preventable events leading to death but did not further categorize them. ${ }^{15,20,21,26}$ The remaining studies provided no information on the types of errors which led to preventable deaths. The most common errors which led to preventable deaths were clinical monitoring and management issues, diagnostic errors, surgery/procedural complications, drug- or fluid-related complications, and errors related to infections or antibiotic choice.

\section{DISCUSSION}

Overall, our systematic review found eight studies of hospitalized patients that reviewed case series of consecutive or randomly selected inpatient deaths and found that $3.1 \%$ of 12,503 deaths were judged to have been preventable. Additionally, two studies reported rates of preventable deaths for patients with at least 3 months life expectancy and reported that between 0.5 and $1.0 \%$ of these deaths were preventable. If these rates are multiplied by the number of annual deaths of hospitalized patients in the USA, our estimates equate to approximately 22,165 preventable deaths annually and up to 7150 preventable deaths among patients with greater than 3 months life expectancy. ${ }^{31}$

These results contrast with earlier estimates of medical error which reported higher rates of preventable mortality. The IOM report as well as similar subsequent reviews has reported much 
Table 2 Characteristics of Included Studies of Cohorts with Selection Criteria

\begin{tabular}{|c|c|c|c|c|c|c|c|}
\hline$\overline{\text { Author }}$ & Setting & $\begin{array}{l}\text { Number } \\
\text { of deaths } \\
\text { reviewed }\end{array}$ & Cohort & $\begin{array}{l}\text { Definition of } \\
\text { preventable }\end{array}$ & $\begin{array}{l}\text { Determination of } \\
\text { preventable }\end{array}$ & $\begin{array}{l}\text { Inter-rater } \\
\text { reliability for } \\
\text { preventability }\end{array}$ & $\begin{array}{l}\text { Proportion of } \\
\text { preventable } \\
\text { deaths }\end{array}$ \\
\hline \multicolumn{8}{|c|}{ Selected cohorts with comparable definitions of preventable } \\
\hline $\begin{array}{l}\text { Dubois, } \\
1988\end{array}$ & $\begin{array}{l}12 \text { hospitals, } \\
\text { USA }\end{array}$ & 182 & $\begin{array}{l}\text { Only patients with } \\
\text { AMI, pneumonia, } \\
\text { CVA. Selected } \\
\text { outlier hospitals }\end{array}$ & $\begin{array}{l}\text { 4-point scale, } \geq \\
3=\text { preventable }\end{array}$ & $\begin{array}{l}\text { At least } 3 \\
\text { reviewers, } \\
\text { majority rules } \\
\text { arbitration }\end{array}$ & $\begin{array}{l}\text { Kappa } 0.2-0.4 \\
\text { range for the } \\
\text { different } \\
\text { diagnostic } \\
\text { groups }\end{array}$ & $\begin{array}{l}49 / 182 \\
(26.9 \%)\end{array}$ \\
\hline $\begin{array}{l}\text { Hayward, }^{24} \\
2001\end{array}$ & $\begin{array}{l}7 \text { VA } \\
\text { hospitals, } \\
\text { USA }\end{array}$ & 111 & $\begin{array}{l}\text { Oversampled for } \\
\text { certain diagnoses. } \\
\text { Excluded end of } \\
\text { life admissions }\end{array}$ & $\begin{array}{l}\text { 5-point scale, } \geq \\
4 \text { = preventable }\end{array}$ & $\begin{array}{l}1-14 \text { reviewers, } \\
\text { weighted sum of } \\
\text { each reviewer's } \\
\text { judgment }\end{array}$ & ICC 0.34 & $6.0 \% *$ \\
\hline $\begin{array}{l}\text { Ksouri, }^{25} \\
2010\end{array}$ & $\begin{array}{l}\text { Single } \\
\text { hospital, } \\
\text { France }\end{array}$ & 260 & $\begin{array}{l}\text { Consecutive ICU } \\
\text { deaths }\end{array}$ & $\begin{array}{l}\text { 4-point scale, } \geq 3 \\
\text { probably or } \\
\text { certainly } \\
\text { preventable }\end{array}$ & $\begin{array}{l}\text { Morbidity and } \\
\text { mortality } \\
\text { conference } \\
\text { consensus }\end{array}$ & NR & $16 / 260(6.2 \%)$ \\
\hline $\begin{array}{l}\text { Goulet }^{26} \\
2015\end{array}$ & $\begin{array}{l}\text { Single } \\
\text { hospital, } \\
\text { France }\end{array}$ & 484 & $\begin{array}{l}\text { Emergency } \\
\text { admission to the } \\
\text { floor who died } \\
\text { within } 72 \mathrm{~h} \text {, } \\
\text { Excluded end of } \\
\text { life admissions }\end{array}$ & $\begin{array}{l}5 \text {-point scale, } \geq \\
4=\text { preventable }\end{array}$ & $\begin{array}{l}2 \text { physicians, } \\
\text { consensus or } \\
\text { expert arbitration }\end{array}$ & Kappa 0.87 & $24 / 47(51.1 \%)$ \\
\hline $\begin{array}{l}\text { Roberts, }{ }^{27} \\
2017\end{array}$ & 4 trusts, UK & 7370 & $\begin{array}{l}\text { Sample of } \\
\text { inpatient deaths } \\
\text { based on incident } \\
\text { reports, } \\
\text { convenience } \\
\text { sample, complaints }\end{array}$ & $\begin{array}{l}6 \text {-point scale, } \geq \\
4=\text { preventable }\end{array}$ & $\begin{array}{l}\text { One physician } \\
\text { reviewer }\end{array}$ & NR & $\begin{array}{l}34 / 7370 \\
(0.5 \%)\end{array}$ \\
\hline \multicolumn{8}{|c|}{ Selected cohorts with different definitions of preventable } \\
\hline Best, $^{28} 1994$ & $\begin{array}{l}48 \text { VA } \\
\text { hospitals, } \\
\text { USA }\end{array}$ & 222 & $\begin{array}{l}\text { Sampled } 5 \\
\text { diagnostic groups }\end{array}$ & $\begin{array}{l}4 \text { point scale, } \\
3=\text { "somewhat } \\
\text { likely," } \\
4=\text { "highly } \\
\text { likely"" }\end{array}$ & $\begin{array}{l}3 \text { physicians, no } \\
\text { arbitration process } \\
\text { described }\end{array}$ & Kappa 0.33 & $\begin{array}{l}48 / 222 \\
(21.6 \%)\end{array}$ \\
\hline $\mathrm{Lu}^{29} 2006$ & $\begin{array}{l}\text { Single } \\
\text { hospital, } \\
\text { Taiwan }\end{array}$ & 210 & $\begin{array}{l}\text { ED admission who } \\
\text { died within } 24 \mathrm{~h} \text {. } \\
\text { Excluded terminal } \\
\text { cancer and out of } \\
\text { hospital cardiac } \\
\text { arrest }\end{array}$ & $\begin{array}{l}\text { Yes/no } \\
\text { preventable }\end{array}$ & $\begin{array}{l}\text { Two physicians, } \\
\text { consensus } \\
\text { arbitration }\end{array}$ & Kappa 0.81 & $\begin{array}{l}32 / 124 \\
(25.8 \%)\end{array}$ \\
\hline $\begin{array}{l}\text { Klein, }^{30} \\
2017\end{array}$ & $\begin{array}{l}\text { Single } \\
\text { hospital, } \\
\text { Netherlands }\end{array}$ & 2182 & $\begin{array}{l}\text { Consecutive } \\
\text { deaths that were } \\
\text { trigger tool } \\
\text { positive }\end{array}$ & $\begin{array}{l}\text { Yes/no } \\
\text { "potentially } \\
\text { contributed" to } \\
\text { death }\end{array}$ & $\begin{array}{l}\text { Committee of } \\
\text { physicians, } \\
\text { consensus }\end{array}$ & NR & $\begin{array}{l}206 / 2182 \\
(9.4 \%)\end{array}$ \\
\hline
\end{tabular}

AMI, acute myocardial infarction; CVA, cerebrovascular accident; VA, Veteran Affairs; ICC, intraclass correlation coefficient; ED, emergency department; ICU, intensive care unit; NR, not reported

*Authors reported adjusted rate of preventable mortality

higher estimates. ${ }^{4}$ Numerous authors have criticized these prior estimates for varied methodologic reasons, ${ }^{5,6}$ including poorly described methods for determining preventability and causality for death, as well as for indirectness - these studies have in common that they primarily attempt to define the incidence of adverse events in series of hospitalized patients and then secondarily estimate the likelihood that the adverse event was preventable and the likelihood that the adverse event, rather than underlying disease, caused the patient's death. The studies we reviewed have the advantage of both using as their denominator a series of inpatient deaths rather than admissions and directly assessing the deaths for preventability.

Our finding that only a small fraction of hospital deaths is preventable and that many preventable deaths occur in patients with less than 3-month life expectancy has several implications. The first relates to patient safety. We agree with others that recent higher estimates of preventable deaths are not plausible and may have served to undermine the credibility of the patient safety movement as well as diverted attention from other patient safety priorities. ${ }^{5}$

Another important implication of our study relates to the use of hospital mortality rates as quality measures. Overall hospital mortality rates and disease-specific mortality rates continue to be reported in many countries in Europe and the USA. $^{32,}{ }^{33}$ In the USA, overall hospital mortality rates are reported by the Veterans Health Administration and disease and procedure-specific mortality rates are used by the Centers for Medicare and Medicaid Services (CMS). Disease-specific mortality rates are also used to determine hospital reimbursement as part of CMS' Hospital Value-Based Purchasing Program. Our results show that the large majority of inpatient deaths are not due to preventable medical error. Given this finding, variation in hospital mortality rates is more likely due to variation in disease severity and non-disease-related factors that affect the location of a patient's death. Although disease severity is taken into account through the reporting of adjusted 
Table 3 Study Quality Assessment

\begin{tabular}{|c|c|c|c|c|c|c|c|c|}
\hline$\overline{\text { Author }}$ & Representativeness & $\begin{array}{l}\text { Ascertainment } \\
\text { of exposure }\end{array}$ & $\begin{array}{l}\text { Ascertainment: } \\
\text { two reviewers } \\
\text { with IRR } \\
\text { reported }\end{array}$ & $\begin{array}{l}\text { Ascertainment: } \\
\text { criteria for } \\
\text { preventability } \\
\text { specifically } \\
\text { defined }\end{array}$ & $\begin{array}{l}\text { Outcome } \\
\text { not } \\
\text { present at } \\
\text { start of } \\
\text { the study }\end{array}$ & $\begin{array}{l}\text { Assessment } \\
\text { of outcome }\end{array}$ & $\begin{array}{l}\text { Was } \\
\text { follow- } \\
\text { up long } \\
\text { enough? }\end{array}$ & NOS \\
\hline \multicolumn{9}{|c|}{ Random or consecutive cohorts } \\
\hline $\begin{array}{l}\text { Engel, } \\
2007\end{array}$ & $*$ & $*$ & - & $*$ & $*$ & $*$ & $*$ & $6 / 7$ \\
\hline $\begin{array}{l}\text { Hogan, }{ }^{16} \\
2012\end{array}$ & * & $*$ & * & * & * & * & * & $7 / 7$ \\
\hline $\begin{array}{l}\text { Sorinola, }{ }^{17} \\
2012\end{array}$ & $*$ & $*$ & - & $*$ & $*$ & $*$ & $*$ & $6 / 7$ \\
\hline${ }_{2015}$ Baines, $^{18}$ & $*$ & $*$ & $*$ & $*$ & $*$ & $*$ & $*$ & $7 / 7$ \\
\hline $\begin{array}{l}\text { Hogan, } \\
2015\end{array}$ & $*$ & $*$ & * & $*$ & $*$ & $*$ & $*$ & $7 / 7$ \\
\hline $\begin{array}{l}\text { Flaatten, }{ }^{20} \\
2017\end{array}$ & $*$ & $*$ & - & * & $*$ & * & * & $6 / 7$ \\
\hline $\begin{array}{l}\text { Kobewka, }{ }^{21} \\
2017\end{array}$ & $*$ & $*$ & * & * & $*$ & * & * & $7 / 7$ \\
\hline $\begin{array}{l}\text { Rogne, }^{22} \\
2019\end{array}$ & $*$ & $*$ & - & $*$ & $*$ & $*$ & $*$ & $6 / 7$ \\
\hline Selected cohor & and comparable defin & ions of preventable & & & & & & \\
\hline $\begin{array}{l}\text { Dubois, }^{23} \\
1988\end{array}$ & - & $*$ & $*$ & $*$ & $*$ & $*$ & $*$ & $6 / 7$ \\
\hline${ }_{2001}$ Hayward, $^{24}$ & - & $*$ & * & * & $*$ & * & $*$ & $6 / 7$ \\
\hline $\begin{array}{l}\text { Ksouri, }^{25} \\
2010\end{array}$ & - & $*$ & - & $*$ & $*$ & $*$ & $*$ & $5 / 7$ \\
\hline $\begin{array}{l}\text { Goulet, }^{26} \\
2015\end{array}$ & - & $*$ & $*$ & $*$ & $*$ & $*$ & $*$ & $6 / 7$ \\
\hline $\begin{array}{l}\text { Roberts, } \\
2017 \\
\text { Selected cohor }\end{array}$ & $\begin{array}{l}- \\
\text { and different definitio }\end{array}$ & $*$ & - & $*$ & $*$ & $*$ & $*$ & $5 / 7$ \\
\hline Best, ${ }^{28} 1994$ & - & $*$ & * & * & $*$ & * & * & $6 / 7$ \\
\hline $\mathrm{Lu}^{29} 2006$ & - & $*$ & $*$ & - & $*$ & $*$ & $*$ & $5 / 7$ \\
\hline $\begin{array}{l}\text { Klein }{ }^{30} \\
2017\end{array}$ & - & $*$ & - & - & * & $*$ & * & $4 / 7$ \\
\hline
\end{tabular}

IRR, inter-rater reliability; NOS, Newcastle Ottawa Scale

*Asterisk indicates item achieves one point on the NOS

mortality rates, numerous critiques have pointed out the limitations of this approach. ${ }^{34-37}$

Even if disease patterns and severity were uniform, however, there would likely be variation in hospital mortality rates because of variation in the use of hospitals at the end of life. ${ }^{28 \text {, }}$

${ }^{37}$ If it is assumed that the vast majority of hospital deaths are unavoidable, then variation in inpatient mortality should be seen as a measure of where patients die, rather than whether they die. Numerous studies have found that many non-diseaserelated factors affect location of death, including referral to palliative care, home support, living situation, functional status, and patient and family preferences. ${ }^{38}$

Our study has several limitations. The most important is that the included studies rely on physician judgment to determine whether death was preventable. The actual accuracy of this method is unknown since there is no alternative gold standard. Physician review has multiple potential biases that could affect the estimated rate of preventable death, such as hindsight bias after poor outcomes. ${ }^{16,24,39}$ Physician reviews are also based on retrospective chart reviews, which may lack important information relevant to management and death. Another well-described limitation with physician review is poor inter- rater reliability. ${ }^{32}$ Indeed, the inter-rater reliability for preventable death of included studies was generally in the fairmoderate range.

Another limitation of our study was the finding of high statistical heterogeneity. This is likely due to the clinical and methodologic differences of the included studies. The study by Flaatten et al., for example, had the lowest rate of preventable mortality among the studies in the meta-analysis. The authors speculated that this was because in Norway there is no separate inpatient hospice system and therefore patients are frequently admitted for end-of-life care. These patients were routinely found to have had non-preventable deaths and this may have contributed to the low overall rate of preventable mortality compared to studies from countries that have separate hospice systems. The limited number of studies in our review precluded subgroup analysis or meta-regression.

A limitation of our study is also the limited geographic representation due to a lack of studies from the USA. The eight studies included in the meta-analysis are from Europe and Canada. The three studies from the USA were not included in the meta-analysis since they used selected cohorts of patients with an oversampling of specific conditions, and thus 


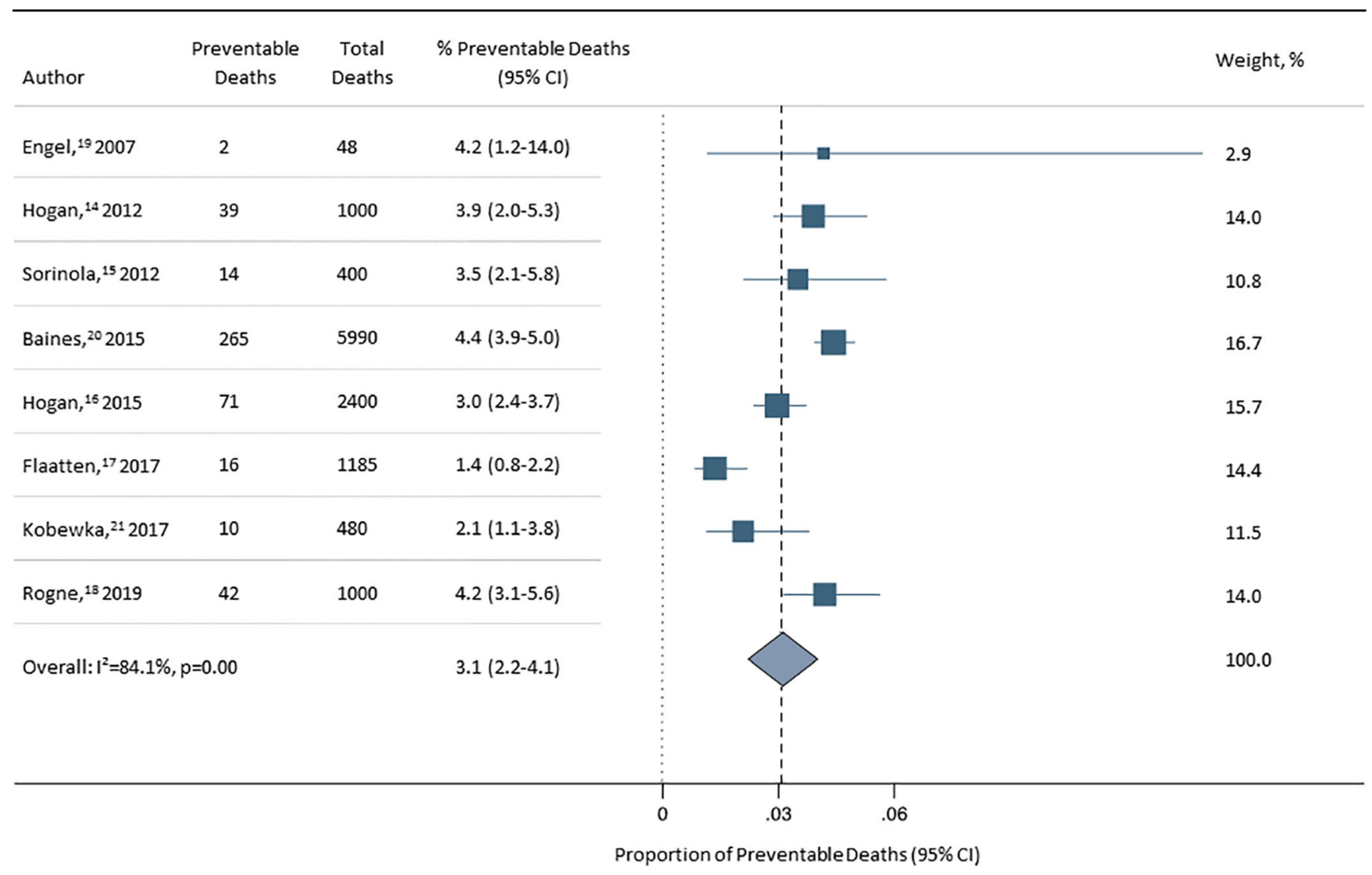

Figure 2 Differences in rates of preventable inpatient mortality.

per protocol were not pooled with studies of consecutive or randomly selected cohorts. Another limitation of the included studies is that six of the eight studies in the meta-analysis included medical errors from prior admissions or prior outpatient care. This could potentially lead to an overestimation of the number of preventable deaths that occurred from events during the index hospitalization. Only the study by Hogan in 2012 separately reported the number of preventable deaths that occurred during the admission alone versus the number that included preventable events prior to the admission. ${ }^{16}$ This study found that $25 \%$ of preventable deaths were related to prior outpatient events, meaning that our estimate may overstate deaths that were preventable due to care in the hospital by as much as $25 \%$. In light of policy changes that focus on episodes of care rather than isolated admissions, further research is needed to study preventable errors prior to and after hospitalization which subsequently result in death.

Lastly, our study is limited only to preventable mortality and does not include estimates of preventable morbidity, another critical aspect of patient safety. While the rate of preventable mortality in hospitalized patients is lower than is often reported, it still represents what would be the 15 th leading cause of death in the $\mathrm{USA}^{40}$ and deserves the continued attention of clinicians, hospital administrators, and policy makers.

In conclusion, we found that $3.1 \%$ of inpatient deaths are judged by physician review to have been preventable. This rate is lower than previous estimates and implies that the vast majority of inpatient deaths are due to underlying disease and not due to variation in quality of care. This has implications for the use of hospital mortality rates for quality reporting and reimbursement.

Corresponding Author: Benjamin A. Rodwin, MD; Department of Medicine Yale University School of Medicine, New Haven, CT, USA (e-mail: Benjamin.Rodwin@yale.edu).

\section{Compliance with Ethical Standards:}

Conflict of Interest: The authors declare that they do not have a conflict of interest.

\section{REFERENCES}

1. Kohn LT, Corrigan JM, Donaldson MS, eds. Committee on Quality of Health Care in America IoM. To Err Is Human: Building a Safer Health System. Washington, D.C.: National Academy Press; 1999.

2. Brennan TA, Leape LL, Laird NM, et al. Incidence of adverse events and negligence in hospitalized patients. Results of the Harvard Medical Practice Study I. N Engl J Med. 1991;324(6):370-376.

3. Thomas EJ, Studdert DM, Burstin HR, et al. Incidence and types of adverse events and negligent care in Utah and Colorado. Med Care. 2000;38(3):261-271.

4. Makary MA, Daniel M. Medical error-the third leading cause of death in the US. BMJ. 2016;353:i2139.

5. Shojania KG, Dixon-Woods M. Estimating deaths due to medical error: the ongoing controversy and why it matters. BMJ Qual Saf. $2017 ; 26(5): 423-428$. 
6. Sox HC Jr, Woloshin $\mathbf{S}$. How many deaths are due to medical error? Getting the number right. Eff Clin Pract. 2000;3(6):277-283.

7. Stroup DF, Berlin JA, Morton SC, et al. Meta-analysis of observational studies in epidemiology: a proposal for reporting. Meta-analysis Of Observational Studies in Epidemiology (MOOSE) group. JAMA. 2000;283(15):2008-2012.

8. Moher D, Liberati A, Tetzlaff J, Altman DG, Group P. Preferred reporting items for systematic reviews and meta-analyses: the PRISMA statement. BMJ. 2009;339:b2535.

9. Grey Matters: a practical tool for searching health-related grey literature. 2018; https://www.cadth.ca/resources/finding-evidence/grey-matters. Accessed 24 July 2018.

10. Jackson JL, Kuriyama A, Anton A, et al. The Accuracy of Google Translate for Abstracting Data From Non-English-Language Trials for Systematic Reviews. Ann Intern Med. 2019.

11. Wells GA SB, O'Connell D, Peterson J, Welch V, Losos M, Tugwell P. The Newcastle-Ottawa Scale (NOS) for assessing the quality of nonrandomized studies in meta-analysis. http://www.ohri.ca/programs/clinical_epidemiology/oxford.asp. Accessed 29 Nov 2018.

12. Nyaga VN, Arbyn M, Aerts M. Metaprop: a Stata command to perform meta-analysis of binomial data. Arch Public Health. 2014;72(1):39.

13. DerSimonian R, Laird N. Meta-analysis in clinical trials. Control Clin Trials. 1986;7(3):177-188

14. Freeman MF, Tukey $\mathbf{J W}$. Transformations related to the angular and the square root. Ann Math Stat. 1950:607-611.

15. Engel C, Rasmussen LL, Nielsen JB, Nielsen SF. [Potentially preventable deaths in a medium sized community hospital]. Ugeskr Laeger. 2007;169(33):2630-2633.

16. Hogan H, Healey F, Neale G, Thomson R, Vincent C, Black $\mathbf{N}$. Preventable deaths due to problems in care in English acute hospitals: a retrospective case record review study. BMJ Qual Saf. 2012;21(9):737745 .

17. Sorinola OO, Weerasinghe C, Brown R. Preventable hospital mortality: learning from retrospective case record review. JRSM Short Rep. 2012;3(11):77.

18. Baines RJ, Langelaan M, de Bruijne MC, Wagner C. Is researching adverse events in hospital deaths a good way to describe patient safety in hospitals: a retrospective patient record review study. BMJ Open. 2015;5(7):e007380.

19. Hogan H, Zipfel R, Neuburger J, Hutchings A, Darzi A, Black N. Avoidability of hospital deaths and association with hospital-wide mortality ratios: retrospective case record review and regression analysis. BMJ. 2015;351:h3239.

20. Flaatten H, Brattebo G, Alme B, et al. Adverse events and in-hospital mortality: an analysis of all deaths in a Norwegian health trust during 2011. BMC Health Serv Res. 2017;17(1):465.

21. Kobewka DM, van Walraven C, Taljaard M, Ronksley P, Forster AJ. The prevalence of potentially preventable deaths in an acute care hospital: A retrospective cohort. Medicine (Baltimore). 2017;96(8):e6162.

22. Rogne T, Nordseth T, Marhaug G, et al. Rate of avoidable deaths in a Norwegian hospital trust as judged by retrospective chart review. BMJ Qual Saf. 2019;28(1):49-55

23. Dubois RW, Brook RH. Preventable deaths: who, how often, and why? Ann Intern Med. 1988;109(7):582-589.
24. Hayward RA, Hofer TP. Estimating hospital deaths due to medical errors: preventability is in the eye of the reviewer. JAMA. 2001;286(4):415-420.

25. Ksouri H, Balanant PY, Tadie JM, et al. Impact of morbidity and mortality conferences on analysis of mortality and critical events in intensive care practice. Am J Crit Care. 2010;19(2):135-145; quiz 146.

26. Goulet H, Guerand V, Bloom B, et al. Unexpected death within 72 hours of emergency department visit: were those deaths preventable? Crit Care. 2015; 19: 154

27. Roberts AP, Morrow G, Walkley M, et al. From research to practice: results of 7300 mortality retrospective case record reviews in four acute hospitals in the North-East of England. BMJ Open Qual. 2017;6(2):e000123.

28. Best WR, Cowper DC. The ratio of observed-to-expected mortality as a quality of care indicator in non-surgical VA patients. Med Care. 1994;32(4):390-400.

29. Lu TC, Tsai CL, Lee CC, et al. Preventable deaths in patients admitted from emergency department. Emerg Med J. 2006;23(6):452-455.

30. Klein DO, Rennenberg R, Koopmans RP, Prins MH. The ability of triggers to retrospectively predict potentially preventable adverse events in a sample of deceased patients. Prev Med Rep. 2017;8:250-255.

31. Hall M, Levant S, DeFrances C. Trends in Inpatient Hospital Deaths: National Hospital Discharge Survey, 2000-2010. 2013; https://www.cdc. gov/nchs/products/databriefs/db118.htm. Accessed 28 Sept 2018.

32. Manaseki-Holland S, Lilford RJ, Te AP, et al. Ranking Hospitals Based on Preventable Hospital Death Rates: A Systematic Review With Implications for Both Direct Measurement and Indirect Measurement Through Standardized Mortality Rates. Milbank Q. 2019;97(1):228-284.

33. Pross C, Geissler A, Busse R. Measuring, Reporting, and Rewarding Quality of Care in 5 Nations: 5 Policy Levers to Enhance Hospital Quality Accountability. Milbank Q. 2017;95(1):136-183.

34. Ioannidis JP. Are mortality differences detected by administrative data reliable and actionable? JAMA. 2013;309(13):1410-1411.

35. Lilford R, Mohammed MA, Spiegelhalter D, Thomson R. Use and misuse of process and outcome data in managing performance of acute medical care: avoiding institutional stigma. Lancet. 2004;363(9415):1147-1154.

36. Lilford R, Pronovost P. Using hospital mortality rates to judge hospital performance: a bad idea that just won't go away. BMJ. 2010;340:c2016.

37. Holloway RG, Quill TE. Mortality as a measure of quality: implications for palliative and end-of-life care. JAMA. 2007;298(7):802-804.

38. Costa V, Earle CC, Esplen MJ, et al. The determinants of home and nursing home death: a systematic review and meta-analysis. BMC Palliat Care. 2016;15:8

39. Zegers M, de Bruijne MC, Wagner C, Groenewegen PP, van der Wal G, de Vet HC. The inter-rater agreement of retrospective assessments of adverse events does not improve with two reviewers per patient record. J Clin Epidemiol. 2010;63(1):94-102.

40. Kochanek K, Murphy S, Xu J, Arias E. Deaths: Final Data for 2017. Natl Vital Stat Rep. 2019. https://www.cdc.gov/nchs/data/nvsr/ nvsr68/nvsr68_09-508.pdf. Accessed 7 Oct 2019.

Publisher's Note Springer Nature remains neutral with regard to jurisdictional claims in published maps and institutional affiliations. 